\title{
Benefit of pregnancy in inflammatory arthritis
}

\section{R H Straub, F Buttgereit, M Cutolo}

not always being secreted by immune cells. ${ }^{13}$ Although the Th2 paradigm is an oversimplification in reproductive immunology, it was initially useful but now needs to be complemented by several other important elements (for further reading see Chaouat et $a l^{13}$ ).

\section{Th2 DOMINANCE IN PREGNANT PATIENTS WITH INFLAMMATORY ARTHRITIS - AND BEYOND}

The first indication that Thl pathways are suppressed in pregnant patients with RA was provided by Russell et al in 1997. ${ }^{14}$ Whole blood cultures stimulated by lipopolysaccharide were shown to release less interleukin (IL) 2 but more soluble tumour necrosis factor (TNF) receptor p55 and p75 during pregnancy. In their study serum TNF and ILl $\beta$ concentrations were unchanged. ${ }^{14}$

In addition, other authors demonstrated decreased IFN $\gamma$, IL12 and increased IL6 production by lymphocytes after phytohaemagglutinin stimulation in third trimester pregnant women with RA as compared with healthy pregnant woman without RA. ${ }^{15}$ This study was complemented by data in patients with RA (third trimester pregnancy) which showed that ex vivo monocytic IL12 production was about threefold and TNF production was approximately $40 \%$ lower than postpartum values. ${ }^{16}$ In a prospective longitudinal study, increased levels of IL10 were found in pregnant women with RA or SLE as compared with healthy pregnant controls. ${ }^{17}$ Interestingly, a similar phenomenon for IL10 was confirmed in patients with SLE, whereas a lower than expected increase of IL6 was found in third trimester pregnancy. ${ }^{18}$

In their study, Østensen et al longitudinally studied plasma and serum samples of pregnant patients with RA, with juvenile idiopathic arthritis, and with ankylosing spondylitis, and they compared these groups with samples from healthy pregnant women. ${ }^{2}$ Clinical assessment and blood sampling in pregnant women was done once in each trimester and 6, 12, and 24 weeks post partum.

Significantly higher concentrations of the soluble TNF receptor p75 and ILl receptor antagonist (ILIRa) were measured in pregnant than in non-pregnant women. ${ }^{2}$ An increase of ILIRa from the second to the third trimester correlated with improvement of disease activity both in patients with RA and those with ankylosing spondylitis.

Compared with non-pregnant patients and with the other pregnant women, patients with RA had markedly raised levels of soluble CD30 during pregnancy. ${ }^{2}$ CD30 (Ki-l) antigen has found to participate in the inflammatory process in RA; this finding was and cytokines have role in local tissue remodelling while 
been considered to be expressed on haematopoietic cells (for example, Reed-Sternberg cells of Hodgkin's disease) but also on non-haematopoietic cells such as human decidual cells.

It is thought that CD30 is a relatively specific marker for Th2 lymphocytes, which is not expressed on Thl cells. ${ }^{19}$

All these data in pregnant women with inflammatory arthritis indicate a Th2 dominance which may be even more pronounced than in healthy pregnant women. In addition, the work by Østensen et al and Russell et al demonstrate that important anti-inflammatory factors, such as soluble TNF receptors and ILIRa, are up regulated. Furthermore, these studies indicate that favourable changes during pregnancy reverse after delivery, leading to increased disease activity. The question is whether or not pregnancy is accompanied by hormonal changes which might modulate immune mechanisms.

\section{Th2 DOMINANCE AND PREGNANCY HORMONES}

During the course of normal pregnancy, hormones such as cortisol, dehydroepiandrosterone (DHEA), progesterone, oestrogens, and norepinephrine strongly increase (summarised by Kanik and Wilder $^{20}$ ). For example, during pregnancy progesterone serum levels increase by a factor of four and oestriol serum concentrations increase by a factor of 20 (which can be regarded as a pharmacologically high dose). Of these hormones, cortisol, oestrogens, norepinephrine, and particularly, progesterone induce a Th2 pathway predominance (table 1). In addition, these hormones and the sex hormone precursor DHEA inhibit many proinflammatory macrophage functions (table 1). These hormones are needed to establish an immune tolerant milieu in the uterus in order to prevent the rejection of the semiallogeneic fetus.

The role of progesterone for inhibition of CD8+ lymphocyte mediated fetal rejection has recently been documented in a mouse model..$^{21}$ Other groups have demonstrated that oestriol altered the cytokine profile of human $\mathrm{T}$ lymphocytes towards a Th2 phenotype by up regulating the production of IL10 and inhibiting TNF secretion of T cells. ${ }^{22}$

\section{"Might pregnancy be accompanied by hormonal changes which mod- ulate immune mechanisms?"}

Further characterisation indicated that oestriol inhibited nuclear transcription factor $\kappa \mathrm{B}(\mathrm{NF}-\kappa \mathrm{B}) .^{22}$ Interestingly, these effects are only observed at a very high concentration of oestriol of $20 \mathrm{ng} /$ $\mathrm{ml}$, which is similar to the serum concentration in late pregnancy. Normally, oestriol is not measurable in the serum of men and women, and only low concentrations of oestriol are expected in peripheral tissues as there is little conversion of precursor hormones. Low concentrations may be proinflammatory, whereas typically higher pregnancy oestriol levels can be regarded as anti-inflammatory. The important effects of high doses of oestriol were further supported in a pilot clinical trial with oral oestriol treatment of patients with relapsing remitting multiple sclerosis ${ }^{23}$ : peripheral blood mononuclear cells collected longitudinally during the trial were given different stimuli, and it was demonstrated that supernatant levels of IL5 and IL10 increased, whereas levels of TNF decreased during oestriol treatment. $^{23}$

In addition, norepinephrine stimulates a Th2 phenotype through the $\beta_{2}$ adrenoceptor. $^{24} 25$ Norepinephrine is
Table 1 Immunomodulation by adrenal/gonadal hormones and sympathetic and sensory neurotransmitters. ${ }^{37}$

\begin{tabular}{ll}
\hline Hormone & Modulation of innate and adaptive immune functions \\
\hline Cortisol & $\begin{array}{l}\text { Inhibition of oxidative burst, phagocytosis, collagenase production, antigen } \\
\text { presentation, COX-2, ILI, IL2, IL6, IL12, IFN } \gamma \text {, TNF etc, support of Th2 } \\
\text { pathways (together with norepinephrine) }\end{array}$ \\
Inhibition of oxygen radical production, ILI, IL6, TNF \\
Oestrogen \\
$\begin{array}{l}\text { Inhibition of IL1, IL6, TNF (pharmacologically high concentration), } \\
\text { stimulation of immunoglobulin production (physiological concentration) }\end{array}$ \\
$\begin{array}{l}\text { Inhibition of T helper 1 pathways, increase of Thelper 2 pathways, increase } \\
\text { of CD30 expression on T cells, inhibition of TNF, IL1 } \beta \text {, and IL6 }\end{array}$ \\
$\begin{array}{l}\text { Inhibition of oxygen radicals, phagocytosis, NK cell activity, HLA class II } \\
\text { adrenoceptors) }\end{array}$ \\
$\begin{array}{l}\text { expression, IL2, IFN } \gamma \text {, IL12, TNF, increase of Th2 pathways (together with } \\
\text { cortisol) }\end{array}$ \\
$\begin{array}{l}\text { COX-2, cyclo-oxygenase type II; DHEA, dehydroepiandrosterone; HLA, human lymphocyte antigen; IL, } \\
\text { interleukin; IFN, interferon; NK, natural killer cell; TNF, tumour necrosis factor. }\end{array}$
\end{tabular}

supported by cortisol owing to cooperative effects of the two hormones, which lead to an increase in glucocorticoid receptors, $\beta$ adrenoceptors, intracellular cyclic AMP, protein kinase A, and cAMP responsive, element binding protein, a sequence of events which has been demonstrated in various cell types. ${ }^{26-34}$ Similar cooperation between norepinephrine and cortisol has recently been demonstrated in mixed synovial cells of patients with RA. ${ }^{35}$ Owing to an increase of norepinephrine and cortisol in pregnancy, these two hormones may additionally support a Th2 predominance and a macrophage suppressive environment.

The question appears to be whether or not hormones during pregnancy in patients with RA or ankylosing spondylitis are normal as compared with those in healthy subjects. The present data do not indicate a large difference in typical pregnancy hormones in patients with RA or ankylosing spondylitis as compared with healthy controls. ${ }^{2}{ }^{16}$ Interestingly, recent studies in pregnant patients with SLE showed different hormonal changes than in healthy pregnant subjects. ${ }^{36}$ Oestradiol and progesterone showed the most relevant alterations because both were significantly lower than expected in pregnant women with SLE in the second and to a greater extent in the third trimester, periods in which these hormones are predominantly secreted by the placenta. Thus, the decrease in their serum concentration might suggest placental dysfunction. In fact, placental alterations related to a decidual vasculopathy/ coagulopathy and/or chronic villitis of unknown aetiology are frequently reported in SLE pregnancies, even in the absence of known risk factors, such as antiphospholipid antibodies. These problems seem to be specific to SLE as they were not reported in inflammatory arthritis.

\section{CONCLUSION}

The present data led to the hypothesis that pregnancy related hormones provide an anti-inflammatory milieu. This is (a) supportive for successful reproduction, and $(b)$ also positively influences inflammatory arthritis. Pregnancy-specific immune changes occur predominantly at the maternalfetal interface, but these changes also elicit systemic effects in the maternal circulation and at sites distant from the uterus. Although all studies in humans are associative in nature, this hypothesis is based on relatively good clinical evidence. Future therapeutic studies with pharmacologically high doses of oestriol or progesterone in RA, ankylosing spondylitis, or psoriatic arthritis may 
shed new light on this intriguing question. The accidental finding that pregnancy is favourable in these diseases suggests that hormonal factors and neurotransmitters are important players in modulation of the arthritic process.

Ann Rheum Dis 2005;64:801-803.

doi: 10.1136 /ard.2005.037580

\section{Authors' affiliations}

R H Straub, Laboratory of Experimental Rheumatology and

Neuroendocrinoimmunology, Division of Rheumatology, Department of Internal Medicine I, University Hospital Regensburg,

Germany

F Buttgereit, Department of Rheumatology and Clinical Immunology, Charité University

Hospital, Berlin, Germany

M Cutolo, Division of Rheumatology, Department of Internal Medicine and Medical Specialties, San Martino University Hospital, Genova, Italy

Correspondence to: Professor R H Straub Laboratory of Neuroendocrinoimmunology, Department of Internal Medicine I, University Hospital, 93042 Regensburg;

rainer.straub@klinik.uni-regensburg.de

\section{REFERENCES}

1 Hench PS. The ameliorating effect of pregnancy on chronic atrophic (infectious, rheumatoid) arthritis, fibrositis, and intermittent hydrarthrosis. Proc StaffMeetings Mayo Clinic 1938;13:161-7.

2 Østensen M, Förger F, Nelson JL, Schumacher A Hebisch G, Villiger PM. Pregnancy in patients with rheumatic disease: anti-inflammatory cytokines increase in pregnancy and decrease post partum. Ann Rheum Dis 2005;64:839-44

3 Schulze-Koops H. Kalden JR. The balance of Th1/ Th2 cytokines in rheumatoid arthritis. Best Pract Res Clin Rheumatol 2001;15:677-91.

4 Müller-Ladner U, Kriegsmann J, Franklin BN, Matsumoto S, Geiler T, Gay RE, et al. Synovia fibroblasts of patients with rheumatoid arthritis attach to and invade normal human cartilage when engrafted into SCID mice. Am J Pathol 1996; 149:1607-15.

5 Redlich K, Hayer S, Ricci R, David JP, TohidastAkrad M, Kollias $G$, et al. Osteoclasts are essential for TNF-alpha-mediated joint destruction. J Clin Invest 2002;1 10:1419-27.

6 Kazkaz H. Isenberg D. Anti B cell therapy (rituximab) in the treatment of autoimmune diseases. Curr Opin Pharmacol 2004;4:398-402

7 Brand DD, Kang AH, Rosloniec EF. Immunopathogenesis of collagen arthritis. Springer Semin Immunopathol 2003:25:3-18.

8 Masi AT, Bijlsma JW, Chikanza IC, Cutolo M. Neuroendocrine mechanisms in rheumatic diseases. Philadelphia, London, Toronto, Montreal, Sydney, Tokyo: Saunders, 2000.
9 Bijlsma JW, Cutolo M, Straub RH, Masi AT. Clinical aspects of immune neuroendocrine mechanisms in rheumatic diseases. Philadelphia, London, Toronto, Montreal, Sydney, Tokyo: Saunders, 2005

10 Wilder RL. Hormones, pregnancy, and autoimmune diseases. Ann N Y Acad Sci 1998:840:45-50.

11 Wegmann TG, Lin H, Guilbert L, Mosmann TR. Bidirectional cytokine interactions in the maternalfetal relationship: is successful pregnancy a TH2 phenomenon? Immunol Today 1993:14:353-6.

12 Piccinni MP, Romagnani S. Regulation of fetal allograft survival by a hormone-controlled Th1and Th2-type cytokines. Immunol Res 1996; 15:141-50.

13 Chaouat G, Ledee-Bataille N, Dubanchet S, Zourbas S, Sandra O, Martal J. TH1/TH2 paradigm in pregnancy: paradigm lost? Cytokines in pregnancy/early abortion: reexamining the $\mathrm{TH} 1 / \mathrm{TH} 2$ paradigm, Int Arch Allergy Immunol 2004;134:93-119.

14 Russell AS, Johnston C, Chew C, Maksymowych WP. Evidence for reduced Th1 function in normal pregnancy: a hypothesis for the remission of rheumatoid arthritis. J Rheumato 1997;24: 1045-50.

15 Tchorzewski H, Krasomski G, Biesiada L, Glowacka E, Banasik M, Lewkowicz P. IL12, IL6 and IFN-gamma production by lymphocytes of pregnant women with rheumatoid arthritis remission during pregnancy. Mediators Inflamm 2000;9:289-93.

16 Elenkov IJ, Wilder RL, Bakalov VK, Link AA Dimitrov MA, Fisher S, et al. IL12, TNF-alpha, and hormonal changes during late pregnancy and early postpartum: implications for autoimmune disease activity during these times. $J$ Clin Endocrinol Metab 2001;86:4933-8.

17 Munoz-Valle JF, Vazquez-Del Mercado M, Garcia-Iglesias T, Orozco-Barocio G, BernardMedina G, Martinez-Bonilla G, et al. $\mathrm{T}(\mathrm{H}) 1 / \mathrm{T}(\mathrm{H}) 2$ cytokine profile, metalloprotease- 9 activity and hormonal status in pregnant rheumatoid arthritis and systemic lupus erythematosus patients. Clin Exp Immunol 2003;131:377-84.

18 Doria A, Ghirardello A, laccarino L, Zampieri S, Punzi L, Tarricone E, et al. Pregnancy, cytokines, and disease activity in systemic lupus erythematosus. Arthritis Rheum 2004:51:989-95.

19 Piccinni MP, Giudizi MG, Biagiotti R, Beloni L, Giannarini L, Sampognaro S, et al. Progesterone favors the development of human T helper cells producing Th2-type cytokines and promotes both IL4 production and membrane CD30 expression in established Th1 cell clones. J Immunol 1995; 155: 128-33.

20 Kanik KS, Wilder RL. Hormonal alterations in rheumatoid arthritis, including the effects of pregnancy. Rheum Dis Clin North Am 2000;26:805-23.

21 Blois SM, Joachim R, Kandil J, Margni R Tometten M, Klapp BF, et al. Depletion of CD8+ cells abolishes the pregnancy protective effect of progesterone substitution with dydrogesterone in mice by altering the Th1/Th2 cytokine profile. $\mathrm{J}$ Immunol 2004;172:5893-9.

22 Zang YC, Halder JB, Hong J, Rivera VM Zhang JZ. Regulatory effects of estriol on T cell migration and cytokine profile: inhibition of transcription factor NF-kappa B. J Neuroimmunol 2002; 124:106-14.
23 Soldan SS, Alvarez Retuerto Al, Sicotte NL, Voskuhl RR. Immune modulation in multiple sclerosis patients treated with the pregnancy hormone estriol. J Immunol 2003;171:6267-74.

24 Elenkov IJ, Chrousos GP. Stress hormones, Th1/ Th2 patterns, pro/anti-inflammatory cytokines and susceptibility to disease. Trends Endocrinol Metab 1999:10:359-68.

25 Sanders VM. Straub RH. Norepinephrine, the beta-adrenergic receptor, and immunity. Brain Behav Immun 2002;16:290-332.

26 Oikarinen J, Hamalainen L, Oikarinen A Modulation of glucocorticoid receptor activity by cyclic nucleotides and its implications on the regulation of human skin fibroblast growth and protein synthesis. Biochim Biophys Acto 1984:799:158-65.

27 Gruol DJ, Campbell NF, Bourgeois S. Cyclic AMP-dependent protein kinase promotes glucocorticoid receptor function. J Biol Chem 1986:261:4909-14.

28 Nakada MT, Stadel JM, Poksay KS, Crooke ST. Glucocorticoid regulation of beta-adrenergic receptors in 3T3-L1 preadipocytes. Mol Pharmacol 1987; 31:377-84.

29 Dong Y, Aronsson M, Gustafsson JA, Okret S. The mechanism of cAMP-induced glucocorticoid receptor expression. Correlation to cellular glucocorticoid response. J Biol Chem 1989;264:13679-83.

30 DiBattista JA, Martel-Pelletier J, Cloutier JM, Pelletier JP. Modulation of glucocorticoid receptor expression in human articular chondrocytes by CAMP and prostaglandins. J Rheumatol Suppl 1991;27:102-5.

31 Korn SH, Wouters EF, Wesseling G, Arends JW, Thunnissen FB. Interaction between glucocorticoids and beta2-agonists: alpha and beta glucocorticoid-receptor mRNA expression in human bronchial epithelial cells. Biochem Pharmacol 1998:56:1561-9.

32 Eickelberg $\mathrm{O}$, Roth $\mathrm{M}$, Lorx R, Bruce V, Rudiger J, Johnson $M$, et al. Ligand-independent activation of the glucocorticoid receptor by beta2adrenergic receptor agonists in primary human lung fibroblasts and vascular smooth muscle cells. $J$ Biol Chem 1999;274:1005-10.

33 Schmidt P, Holsboer F, Spengler D. beta(2)Adrenergic receptors potentiate glucocorticoid receptor transactivation via $G$ protein betagamma-subunits and the phosphoinositide 3kinase pathway. Mol Endocrino 2001; 15:553-64.

34 Sanden S, Tripmacher R, Weltrich R, Rohde W, Hiepe F, Burmester GR, et al. Glucocorticoid dose dependent downregulation of glucocorticoid receptors in patients with rheumatic diseases. J Rheumato 2000;27:1265-70.

35 Straub RH, Günzler C, Miller LE, Cutolo M Schölmerich J, Schill S. Anti-inflammatory cooperativity of corticosteroids and norepinephrine in rheumatoid arthritis synovial tissue in vivo and in vitro. FASEB 2002; 16:993-1000

36 Doria A, Cutolo M, Ghirardello A, Zampieri S, Vescovi F, Sulli A, et al. Steroid hormones and disease activity during pregnancy in systemic lupus erythematosus. Arthritis Rheum 2002:47:202-9.

37 Straub RH. Tables of molecular and functional neuroendocrine immune interactions. Eching, Germany: Biozol, 2000. 